\title{
1. Social security as a human right: A European perspective
}

\author{
Eberhard Eichenhofer
}

\section{A HUMAN RIGHTS PERSPECTIVE ON SOCIAL SECURITY}

\section{I.i Social Security - A Multifaceted Institution}

The concept of social security is vague and the idea of social rights as human rights is highly controversial. So, it is worthwhile to outline the origin of the concept of social security. In doing this, it is necessary to illustrate its overall importance in the framework of a post-World War II reconstruction of Europe and the world. During this era the idea of social human rights also gained enormous momentum; it brought about the international turn in the development of human rights.

Social security has many facets. It matters in a social context as a means to transfer income and to give access to medical, educational and rehabilitative services in order to re-integrate its recipients into the labour market. Due to its costs, social security is also of outstanding economic importance. So, it is a central, constant and controversial matter of politics in each state and it contributes substantially to big government. Just as it drives and deepens social justice, it also raises profound questions on social philosophy.

\section{I.ii Social Security as a Matter of Law}

Social security is created by legislation as an important matter of law. It assumes different dimensions. In legal analysis social security represents a part of the legal system of all advanced societies. It represents a substantial part of public administration, which is not primarily focused on limiting individual freedom, levying taxes or discerning lawful from unlawful actions, but is a service-rendering institution, and, thus, reveals its benevolent side. Social administration is not conceived as embarrassing individuals in their freedom, but as bringing about individual freedom. To make those substantial payments or services feasible, it also levies substantial contributions as well.

Social security also creates legal, individually enforceable entitlements. Benefits in social security are not public alms, as they are not one-sided transfers of money or service from the public purse to the individual. The transfer organised by social security is embedded in a legal relationship, if the legal requirements are met by the beneficiary on the latter's application and the administration confirms that the prerequisites of the legal entitlement are fulfilled, and, so, social administration delivers pensions, unemployment payments or health care on a mandatory basis. 


\section{Research handbook on European social security law}

\section{I.iii Social Security as Human Right}

The human right to social security found its first expression as an international legal guarantee in the Universal Declaration of Human Rights of 10 December 1948. It gave rise to social rights as human rights of the second generation within an international system to secure human rights, established by this instrument in the first instance as a non-binding declaration of principles. This approach changed the conceptual basis of human rights legislation substantially. Before this turn in international rights, human rights were conceived as the key domain of national legislation. World War II made evident, however, that the independent national state can no longer reliably guarantee them. Since Article 22 of the Universal Declaration of Human Rights enacted a human right to social security, each human being is the addressee of this right. Since then social security ${ }^{1}$ has been not only a matter of law and an individual right, but it implies that each human being must have such a right and that it is to be safeguarded by each state. By enacting international human rights the international legislation required the states to build up institutions of social security, in which individual rights to social security are given to each individual and to make the competent state responsible.

The human right of social security made the establishment of a universal and comprehensive system of social security with a wide range of substantial benefits to each human being a mandatory imperative of all states. Under such international human rights legislation the states are no longer free to decide on whether and how they should establish a social security system. Such guarantee implies a system of international provisions on the scope, structure and ways and means of giving shape to social security and corresponding rights provided for by such system. In the context of international law it becomes a matter of international control and supervision whether and to what extent a state complies with the requirements stemming from this human rights commitment.

To analyse the human right to social security, the notion of the concept social security will be clarified (II), its origin and further impact of the international turn in human rights' enactment will be outlined (III), the legal characteristics of social rights will be identified and examined as to whether they can comply with the idea of human rights (IV), and, finally, the content of the human right to social security both on the international and European level will be described and interpreted (V).

1 The concept varies as to different jurisdictions; in the USA it means pensions, in the UK it means benefits in cash and in the EU and the ILO it stands for the system of social protection providing benefits in both cash and in kind. In the subsequent parts of the text the concept is conceived in this latter, broad sense. 


\section{THE CONCEPT OF SOCIAL SECURITY}

\section{II.i History of the Concept}

The concept of social security was created in the USA. When the Social Security Act was adopted in 1935, this law gave a positive answer to the proposals made by the social insurance movement, which emerged during World War I. But this concept was based on the European history of the 19th and 20th centuries, where the idea of the 'Social State' was elaborated by philosophers, lawyers and sociologists such as Hegel, Lorenz von Stein or Tönnies. In this approach the state and the society are not seen as being disconnected from one another, but rather the state should take part in societal development and rebalance unbalanced societies. This development of the intellectual history of Europe in the 19th century is echoed in Article 25 of the Greek Constitution, which makes it mandatory for the state to foster national as well as social solidarity. Awareness grew that the modern state is determined to prevent poverty and destitution. On this basis, by the end of the 19th century social insurance was implemented starting with Central Europe (Germany and the Austrian Hungarian Monarchy), but quickly spreading also to Northern Europe and Western Europe.

The protagonists for social security advocated for its implementation on the basis of a comparative analysis of social insurances in the world - above all in Europe - and for taking such an initiative also in the USA, ${ }^{2}$ to overcome poverty, destitution, bad health and want. This could, and hence should, be made feasible in a society which is able by virtue of its technical and economic potential to get rid also of social hardship. The Social Security Act established social protection in old age, disability, unemployment and - since 1939 - for widows and orphans. It was financed by a federal tax; the latter could be replaced by a contribution in the context of a state-organised unemployment insurance system.

Based upon the experience of this reform Franklin D Roosevelt, the US President of this era of World War II, summarised the aims, after the War ended in success, that the USA intended to drive a world in which the 'four fundamental freedoms' ${ }^{3}$ would be unleashed. These freedoms were both specified and safeguarded. They were characterised by him in the following words:

The first is freedom of speech and expression - everywhere in the world. The second is freedom of every person to worship God in his own way - everywhere in the world. The third is freedom from want - which translated into world terms, means economic undertakings which will secure to every nation a healthy peacetime life for its inhabitants - everywhere in the world. The fourth is freedom from fear - which translated into world terms, means a world-wide reduction of armaments to such a point and in such a function that no nation will

2 Barbara N Armstrong, Insuring the Essentials (Macmillan 1932); Abraham Epstein, Insecurity: A Challenge to America (American Economic Association 1933); Gaston Rimlinger, Welfare Policy and Industrialization in Europe, America and Russia (John Wiley and Sons 1971) 194.

3 Franklin D Roosevelt, 'The Annual Message to the Congress, January 6th, 1941', in Samuel Rosenman, The Public Papers and Addresses of Franklin D. Roosevelt, vol VI (War and Aid to Democracies) (New York 1941) 663 at 672. 


\section{Research handbook on European social security law}

be in a position to commit an act of physical aggression against any neighbour - anywhere in the world.

On 4 August 1941, Winston Churchill and Franklin D Roosevelt - the two leaders of the Western Allies in World War II - agreed on the Atlantic Charter. It represented the principles and targets for the renewal of the world after the military victory over the aggressive Nazi Germany. In Article 5 of this Charter they agreed 'to bring about the fullest collaboration between all nations in the economic field with the object of securing for all, improved labour standards, economic advance and social security'. In Article 6 they imagined the vision of a post-War order based on 'the freedom from fear and want'.

This was the lesson drawn from the experience that social unrest and economic insecurity gave rise to the emergence of Nazi tyranny: 'People who are hungry, and out of a job are the stuff of which dictatorships are made.' ${ }^{4}$ In this context US President Franklin D Roosevelt spoke of 'a second Bill of Rights [with] a new basis of security and prosperity'. This included:

The right to a useful and remunerative job in the industries or shops or farms or mines of the Nation; The right to earn enough to provide adequate food and clothing and recreation; The right of every farmer to raise and sell his products at a return which will give him and his family a decent living; The right of every businessman, large and small, to trade in an atmosphere of freedom from unfair competition and domination by monopolies at home or abroad; The right of every family to a decent home; The right to adequate medical care and the opportunity to achieve and enjoy good health; The right to adequate protection from the economic fears of old age, sickness, accident, and unemployment; The right to a good education. All of these rights spell security. And after this war is won we must be prepared to move forward, in the implementation of these rights, to new goals of human happiness and well-being. 5

\section{II.ii Legal Concept}

As to Article 22 of the Universal Declaration of Human Rights 'everyone, as a member of society, has the right to social security'. This provision on principles of human rights makes clear that social security rights are enshrined in the membership within a given society. Social security is - in other words - embedded in and determined to ensure social inclusion. The formal and official definition of social security is given by ILO Convention No. 102, concluded on 28 June 1952 at the Geneva International Labour Conference. In this instrument social security is characterised by benefits of nine different branches, i.e. medical care and income replacement in the cases of sickness,

4 Franklin D Roosevelt, 'Speech of January 11th, 1944, 'For unless there is security here at home there cannot be lasting peace in the world' - 'Message to the Congress on the State of the Union', in Samuel Rosenman, The Public Papers and Addresses of Franklin D. Roosevelt, vol. VIII, Victory and the Threshold of Peace (New York 1950) 32 at 40.

5 Ibid 41. 
unemployment, old age, employment injury and occupational diseases, family charges, maternity, invalidity and widowhood and the status of an orphan. ${ }^{6}$

This definition is inspired by the social protection, traditionally organised by social insurance, as it had been established since the last decades of the 19th century, in order to protect the working population against the main social risks - risks that stem from participation in the labour market. The protection organised under social security replaces the income lost by a worker in cases when the social contingencies of work happened. In the advanced form of today social security tends to integrate also the non-working, even the non-able-bodied population into its system of protection. In a social security system based on human rights, a universal protection is provided for the whole resident population.

Such protection is based on the implicit assumption of a society based on work. It presupposes that every individual earns his/her living by carrying out some productive or reproductive activities. They bring about an economic return, predominantly by doing dependent work. Returns from productivity should allow each individual to meet his/her needs on the market of consumer goods. If someone becomes unable to work due to circumstances beyond his/her control and hence loses income necessary to afford to live, social security is bound to replace the lost income for those temporarily or permanently out of work.

\section{II.iii The Human Right in National Constitutions}

The Constitutions of the Czech Republic (Article 26 of the Czech Charter of Fundamental Rights), Greece (Article 22), Italy (Article 38), Latvia (Article 10), Lithuania (Article 52), Luxembourg (Article 11), Romania (Articles 34, 41, 47), Slovenia (Article 50), Spain (Article 49), Sweden (Article 2(2)), and Switzerland (Article 41) provide special clauses on social security. They impose on the legislation the commitment to create, maintain and develop systems of social security and define their characteristics. This is done by determining the social risks and the persons covered. On this basis a constitutional right to social security is acknowledged.

This right is very often embedded in a social insurance relationship between an individual and public administration based on residence or employment. This right does not give rise to specific entitlements. ${ }^{7}$ From this follows clearly that legislation has a broad range of discretion as to how to create, establish, delineate and develop the social security system. Nevertheless the constitutional guarantee has a substantial impact, as it stabilises the institutions built to establish social rights. But it does not mean that the given social security legislation should be set in stone for ever as unchangeable rules. Changes are lawful if they are proportionate, reasonable, predictable and fair. Changes in social security legislation should above all rebalance returns and charges between the

6 Frans Pennings, 'The Meaning of International Standards in Social Security', in Jef van Langendonck (ed.), The Right to Social Security (Intersentia 2007) 3; Ulrich Becker, Frans Pennings, Tineke Dijkhoff (eds.), International Standard-setting and Innovations in Social Security (Kluwer Law International 2013).

7 Article 41 of the Czech Charter of Fundamental Rights, Article 131 of the Latvian Constitution and Article 41 para. 4 of the Swiss Constitution. 
beneficiaries and the contributors - as a matter of intergenerational fairness. The impact of the demographic changes in society and on the performance and financing of social security can be readjusted. A reduction of the benefit level can be justified by the prospect of lowering charges for subsequent generations.

So, only in very rare cases of an unbalanced and not proportional retrenchment of benefits was a violation of the right to social security observed. ${ }^{8}$ The explicit constitutional right to social security is not the only means to protect social rights. Also the property clause or the rule of law ${ }^{9}$ are taken as alternative instruments to protect social rights on the constitutional level. In contrast to the classical conception of property, social rights lack any possessive element. This element is criticised as giving the owner of things also power above human beings, if they work with the objects for the owner. If social rights are seen as property, the emphasis is given to benefits, established in social security on the rule of law. This system is built on trust, and this requires continuity of social security systems. This guarantee is given by the Constitution. And even in the absence of a specific constitutional guarantee of social rights, they are protected by a plethora of constitutional principles, e.g. equality, privacy, the protection of life, liberty and estate. ${ }^{10}$

\section{HUMAN RIGHTS' INTERNATIONAL TURN}

\section{III.i Social Security Rights and Social Justice}

Social security benefits should deepen social justice. This concept, however, is controversial and difficult to grasp. Social justice has to safeguard human dignity, equality and individual freedom. Human dignity is based on the insight Hannah Arendt ${ }^{11}$ described when analysing totalitarian governance that each individual has a right to have human rights stemming from the dignity of each human being. So, human dignity is not a human right itself, but represents the overall justification for human rights. Universal human rights are to underpin the dignity of each human being.

Thus, all human beings as created equal are to be respected and as to this are to be treated as equals - despite their enormous differences in reality. The principle of equality of rights neither denies the differences between human beings as to their characteristics, virtues, talents, performances and achievements, nor emphasises equal results in social life. ${ }^{12}$ To the contrary, the market is built upon differences between the participants, because only differences allow the exchange of goods and services on the market. But upon the equality of rights of each one each functioning market is built, as

8 Constitutional Court of Romania decision no 264, 20 March 2007; Decision no 82, 15 January 2009; BVerfGE 100, 138.

9 Above all in Ireland and the North European countries.

10 Eberhard Eichenhofer, 'Constitutional Guarantees of Social Protection', in K Ketscher et al (eds), Velferd og rettferd, Festskrift til Asbjorn Kjonstad, 70 ar (Gyldendal Juridisk 2013) 127; see also G Katrougalos, Chapter 4 in this volume as to recent Court interventions on the basis of constitutional risks.

11 Hannah Arendt, The Origins of Totalitarianism (Harcourt Brace 1960).

12 Bob Hepple, Equality. The New Legal Framework (Hart Publishing 2011). 
it gives open access to each one without hindrance due to personal characteristics. But such market-driven social life is based on competition and this brings about different results for the participants in the market due to their differences in abilities and thrift, chances and efforts. So, despite the fact that equality of rights is a precondition of the market, its outcome is not equally allotted to the various human beings, but there are remarkable differences due to circumstances within or beyond the individual control of the competitors.

Not all differences are unjustified. To the contrary, some of them are to be regarded as fair, such as the remuneration for ambition and devotion, talent and good luck, a high level of education or a special ability. The welfare state does not wipe out these differences, but quite to the contrary, it profits from them, as each productive society is based upon diversity of people and means to draw economic advantages from the different outcomes of different people. The welfare state is not keen on making everybody or everything alike and the society a homogeneous one. Therefore, the ideal of the welfare state is equality, established on the basis of diversity among human beings, which are entitled by the basic human rights to develop themselves as free individuals. In a welfare state legal equality is not enough to safeguard material or social equality. This formal equality is the backbone of the market: but human life is not a race! Competition and struggling for survival are neither the only, nor the ultimate, targets of social life, they are not more than a technical means to draw social profit from human diversity and differences. So, the welfare state embeds social competition into a social structure of human solidarity. This is done in order to cope with human diversity which stems from differences which are beyond individual control: good or bad health, committed or disinterested parents, stimulating or boring education, good luck or pity - no human being is just the product of her- or himself, but at the same time everyone's life depends on certain social conditions that cannot be influenced by the individual.

The welfare state copes with the challenge of diversity among human beings due to conditions beyond their control, as they are supposed to work and in such activity are exposed to risks embedded in the working life of each individual: sickness, work accident, professional diseases, invalidity, unemployment, old age, death of the spouse or parent. As these risks are not adequately, if at all, covered by the market, it is up to society to make social security become an effective instrument of risk management.

Social security strengthens the freedom of the individual, whenever independent life is jeopardised by social risks. Social justice is the aim of social security benefits, which organise social solidarity. They are based upon the market, but safeguard human dignity also to those who are - through no fault of their own - unable to organise a living in human dignity. Social benefits emerge from social rights. The idea of social justice is translated into 'stake-holding'. ${ }^{13}$ It emphasises equal opportunities for all the members of a given society; everyone should have the chance of a fair share - not on the basis of

13 Bruce Ackermann and Anne Alstott, The Stakeholder Society (Yale University Press 1999); Simon Deakin, 'The "Capability" Concept and the Evolution of European Social Policy', in Eleanor Spaventa and Michael Dougan (eds), Social Welfare and EU Law (Hart Publishing 2005) $3 \mathrm{ff}$. 
a handout, but as a social right. So, the concept of social justice is directed and verified by social rights.

The idea of social rights ${ }^{14}$ is based on a double critique civil human rights, which are embedded in the idea of 'negative freedom'15 and the principle of formal = legal equality. Social rights are the reaction to a profound challenge. 'Equal liberty before formally universal laws is no fair guarantee of a common opportunity for access to the good life.' ${ }^{16}$ Social human rights are central to establishing a society based on fairness. 'The main idea is that society is rightly ordered, and therefore just, when its major institutions are arranged so as to achieve the greatest net balance of satisfaction summed over all the individuals belonging to it.' 17 'Social rights are inspired by the idea of positive "freedom". The notion of freedom as effective power to achieve what one could choose is an important part of the general idea of freedom.' ${ }^{18}$ The additional component to justify social rights is the idea of equality of freedoms in the sense that freedoms are to be safeguarded only if each human being can enjoy her or his freedoms. Equality and non-discrimination are not identical:19 each equality or liberty (égalité, liberté) brings about inequality, and not all of them are illegitimate. Nondiscrimination laws are to sanction illegitimate differences.

\section{III.ii Human Rights as International Principles}

The Universal Declaration of Human Rights was the immediate answer to the atrocities of World War II: persecutions, mass murders, expulsions and forced labour, racism, sexism, elitism and any lack of empathy and compassion for 'aliens' who were regarded as 'enemies'. Driven by the intention to establish a lasting peace based on human rights, it had been stipulated that the Universal Declaration of Human Rights would bring about after a 'just war' a 'just peace'.

14 Daphne Barak-Erez and Aeyal Gross (eds), Exploring Social Rights (Hart Publishing 2007); Gerald J Beyer, 'Economic Rights: Past, Present and Future', in Thomas Cushman (ed), Handbook of Human Rights (Routledge 2012) 291; Grainne de Burca and Bruno de Witte (eds), Social Rights in Europe (Oxford University Press 2005); Asbjorn Eide (ed), Economic, Social and Cultural Rights (Martinus Nijhoff 2001); Cecile Fabre, Social Rights under the Constitution. Government and the Decent Life (Oxford University Press 2000); Malcolm Langford, Social Rights Jurisprudence (Cambridge University Press 2008); Matti Mikkola, Social Human Rights of Europe (Legisactio 2010); David A Shiman, Economic and Social Justice, A Human Rights' Perspective (Human Rights Resource Center 1999); Manisuli Ssenyonjo, Economic, Social and Cultural Rights in International Law (Hart Publishing 2009); Iris Marion Young, Justice and the Politics of Difference (Princeton University Press 1990); Jeff King, Judging Social Rights (Cambridge University Press 2012).

15 Isaiah Berlin, Two Concepts of Liberty (Oxford University Press 1958); Isaiah Berlin, Four Essays on Liberty (Oxford University Press 1969) 118.

16 Neil MacCormick, 'Legal Right and Social Democracy', in Neil MacCormick (ed), Legal Right and Social Democracy, Essays in Legal and Political Philosophy (Oxford University Press 1982) 10.

17 John Rawls, Theory of Justice (Oxford University Press 1971) 22.

18 Amartya Sen, Inequality Reexamined (Russell Sage Foundation 1992) 69.

19 Jean-Francois Cesaro, L'égalité en droit social (LexisNexis 2011). 
The Universal Declaration of Human Rights was meant as a declaration of principles to echo the motives for which the Allied forces fought the war they finally won, and which should be respected globally after the War. Based on the conviction that mass unemployment and mass poverty gave rise to Nazism, Article 53 of the UN Charter declares that the raising of standards of living, full employment and social and economic progress based on international co-operation among all states should be the central goals for a post-War international order. Under the Universal Declaration of Human Rights the states are sovereign, but they are committed to respect the Universal Declaration of Human Rights' principles as their 'international bill of rights'. ${ }^{20}$ This declaration 'is not a treaty, it is not an international agreement, it is not and does not purport to be a statement of law or legal obligation. It is a declaration of basic principles of human rights and freedoms... a common standard of an achievement for all peoples and all nations'. ${ }^{21}$

The Universal Declaration of Human Rights is inspired by a new view of human rights, which is radically different from the one that prevailed when human rights had been initially established in the USA and France by the end of the 18th century. At that time, human rights were 'citizens' rights' or, in French, droits de l'homme et du citoyen. $^{22}$ Due to their conceptual basis as civil rights they were reserved to the property owners who took part as entrepreneurs in the market. Due to this delineation the original human rights were privileges in a literal sense for a very few male citizens who had sufficient assets to lead, as self-employed, an economic life in full independence from others. Women, workers, slaves and all foreigners were neither conceived of as citizen, nor entitled to human rights. In this thinking, the human rights were elitist, selective and restricted privileges of a nation state for the economically leading class of nationals, whereas the mass of the population should and could not draw any support from the enactment of human rights.

But the history of the 19th and 20th centuries was a process of emancipation, i.e. driven by a constant process of broadening the personal scope of human rights. After a long and violent phase of social struggle and unrest, which brought societies to the brink of social revolution, a history of emancipation of the great majority began. They were up to this moment deprived not only of human rights, but of rights altogether. Emancipation brought to slaves the abolition of slavery, the full integration of the dependent workers in both civil society and the legal system - the latter by incorporating dependent work in the legal context of contract work and the establishment of enforceable public labour protection as to the worker's health and safety - and finally the equal treatment of men and women in state, society, family and labour law.

All these historically profound changes are reflected in the Universal Declaration of Human Rights, above all as to its personal and substantive scope, where these deep and important changes are reflected. Compared with the human rights proclamations of the past, the international human rights of the Universal Declaration of Human Rights are universal as to their addressees and the freedoms granted. As all human beings benefit

\footnotetext{
20 Mary Ann Glendon, A World Made New (Random House 2001).

21 [1948] 19, 494 Department of State Bulletin 751.

22 Bertrand G Ramcharan, 'Norms and Machinery', in Thomas G Weiss and Sam Daws (eds), The Oxford Handbook on the United Nations (Oxford University Press 2008) 443.
} 


\section{Research handbook on European social security law}

from human rights, irrespective of gender, nationality or civil status, the concept of national citizenship - one crucial for the formation of human rights in the national context - loses its relevance, as citizenship is replaced by other criteria, which are independent from one state. By the international human rights' turn the nation states change their role profoundly; they are no longer to be regarded as independent communities - isolated from one another - but dependent agencies as integral players in the international world of interrelated states.

Such a broad understanding of human rights is supported by anti-discrimination rules. They not only further and deepen equality, but help also to make human rights become effective for everyone - irrespective of gender, ethnic origin, social status, disability and age. Those provisions do not violate human rights as critical comments on those laws had been made upon their implementation. At the same time, they accompany the transition from a traditional reduced and narrow understanding of human rights to the open-minded and wide understanding established by the Universal Declaration of Human Rights.

The human rights in the Universal Declaration of Human Rights also have a wider content than previous enactments. The examples given by the Constitutions of Mexico (1917) and Germany in the Weimar Republic (1919) and Finland (1919, 1995) had been taken over by the Universal Declaration of Human Rights, when it incorporated profound, social rights - rights to work, education, health, assistance, accommodation and social security - as core human rights on the same level and with the same rank as the classical civil and political human rights.

By this enlargement of the scope of human rights the substance of human rights legislation was widened beyond the traditional spheres of civil and political rights. ${ }^{23}$ It underlines the overall importance of social institutions to foster social integration. States are mandated with the formation and development of social policy institutions because of their outstanding importance in fostering social integration and human dignity. Social human rights have an important role to play in improving the social conditions of human existence for the working population and all the vulnerable groups in a market society based on wage-labour. ${ }^{24}$ The implementation of these rights not only puts social rights of the different states on the same international level, but it also - by doing this - revises international economic law.

\section{III.iii Social Security and the Nation State}

A welfare state is aimed at the well-being of each citizen or denizen. So, in such an arrangement the state has an overall important role to play. The state has not only to defend civil liberties and sanction those persons who commit violations. If good health, the relief of poverty and the full participation of each one in the labour market become matters of public concern, the public administration has to safeguard these rights. So, the welfare state stands for big government, a strong and not a weak state, ready to intervene whenever social shortcomings become visible, and keen on organising a

23 See Chapter 5 in this volume.

24 Christine Kaufmann, Globalisation and Labour Rights. The Conflict between Core Labour Rights and International Economic Law (Hart Publishing 2007). 
society in line with high social targets and ideals. So, within a welfare state, government, legislation and administration has a leading role to play. This implies high taxes, a substantial share of public spending and a strong and costly public administration.

For the welfare state democratic governance seems not to be a prerequisite, as also authoritarian regimes do and did have a broad welfare agenda. But nevertheless, democratic governance coincides with the aim of the welfare state most as its major aim to improve the living conditions of the greatest number of the population coincides with the principles of the universal vote, which characterises democracy. As welfare states intend to distribute income, they levy taxes and contributions from income and capital. So, despite the fact that the welfare state regards itself as a benevolent state, it has to take from the many to give to others. To make this redistribution acceptable to all, democratic governance is the best way to legitimise the transfer. So, there is under the perspective of legitimising welfare transfers a bias towards democratic governance.

Bringing about social integration is closely related to another basic function of the state, i.e. to safeguard individual rights - irrespective of whether they are to be characterised as civil, political or social rights. Traditionally the state has to defend, define, protect and effectuate human rights. The state has to protect individuals collectively and to organise their joint living within a given society. By social rights the state and the individuals are tied by a relationship of mutual support. Social rights are, hence, a means to establish a community among the individuals living in a given society.

This community - formed by the welfare state - is not primarily directed towards the citizens, but towards the employed persons and the denizens, as systems of social protection integrate persons on the basis of their employment or residence in a given society. The citizens of a society, who are working and living abroad, are not covered by the institution of the welfare state.

So neither nation-building, nor the idea of social citizenship ${ }^{25}$ and therefore also not the idea of democracy can give any justification for the welfare state - despite the fact that these thoughts play an important and ongoing role in the political rhetoric, which is driven by a widespread nationalist undertone. This legacy stems from the formative era of the modern welfare state, which was indeed the period of wartime, and had also a strong justification in the efforts undertaken to support veterans and victims of war by society at large. So, from a historical and political point of view the welfare state can be regarded as the benevolent type of independent nation state, which transforms society into a coherent community. In this tradition the status of the citizen resumed a key role in the context and definition of social rights.

Under the conditions of international alliances - in Europe, Europeanisation - or the emerging global governance, all the welfare states became more and more open to one another. If access to the different states is free without any restrictions, also social rights can emerge by virtue of work or residence. Social welfare states are now coordinated on an international level by social security agreements or within the EU by

25 For these questions, see Chapter 2 in this volume. A good analysis of the multifaceted concept of citizenship is given by Linda Bosniak, The Citizen and the Alien. Dilemmas of Contemporary Membership (Princeton University Press 2008). 
EU legislation. So, instead of citizenship, denizenship becomes the key justification for the acquisition of social rights.

\section{SOCIAL HUMAN RIGHTS}

\section{IV.i Dimensions: Work, Assistance, Health, Accommodation and Social Security}

The fundamental human rights to work, assistance, education, housing, health and social security are enshrined in Articles 22-26 of the Universal Declaration of Human Rights. Civil and political rights became a central issue in the formative era of the 18th century, when the market society gained ground and democracy become the prevailing model for governance. Social rights were the ultimate outcome of the initial era of industrialisation, which made social inequalities and mass poverty evident and undermined social cohesion, which led industrialised societies to the brink of social revolution. They avoided this peril between the late 19th century and the 20th century by implementing social reforms such as to labour rights, trade union law, collective bargaining, public health and public schooling, an extension and further systematisation of poor law and the creation of social security. Despite their old roots in the late 18th century, when they were envisaged by Thomas Paine in his book, The Right of Man ${ }^{26}$ and for the first time formally acknowledged by the French General Declaration of the Rights of Men and Citizens adopted in 1793 in the French National Assembly, their constitutional acknowledgment became possible only after the legal institutions were established which could make the social rights effective and relevant, so that also corresponding social rights could effectively be proclaimed.

In the academic dispute on social human rights, there is strong doubt as to whether social rights could ever be possible as human rights. If human rights are regarded as guarantees under natural law, meant to identify immunities under state legislation and the definition of negative freedoms, social rights could never be fundamental social rights, as they could not meet any of these requirements. Hence, all social rights lack any naturalistic flavour as they are based on social institutions, to be made by political actions, and they have to create positive freedom, i.e. possibilities to act. But is the legal character of human rights in this alleged picture adequately sketched?

All human rights have to establish freedom within a society. Therefore, they never define spheres of natural freedom. Human rights are not about human nature, but about human society! As they are part of the law, they have to play a leading role within the law! It is, hence, a misconception of human rights to conceive them as a part of natural law. All human rights have a societal strand. ${ }^{27}$ They became an issue in history, only if social conditions were met, when the freedom of the individual became a subject of

26 Thomas Paine, The Right of Man (London 1791); Gerald J Beyer, 'Economic Rights: Past, Present and Future', in Thomas Cushman (ed.), Handbook of Human Rights (Routledge 2012) 292 ff.; David Bilchitz, Poverty and Fundamental Rights: The Justification and Enforcement of Socio-Economic Rights (Oxford University Press 2008) 109.

27 Beyer (n 26) 300; Sandra Fredman, Human Rights Transformed (Oxford University Press 2008). 
dispute within society. The freedom of belief became a controversy in society under reformation when different confessions emerged. The freedom of expression is only important under the assumption of a public sphere, based on unhindered communication and exchanges of different views. For an individual isolated from the rest of society, there is no audience. So to this person, the freedom of expression is without any importance. The right to marriage requires a partner: if there is no one to marry, the right would be without any importance. If so, human rights are addressed to the members of the human species not as human beings, but as members of the human society of women and men which organises their joint living based on market exchanges in a democratic political order framed by a comprehensive welfare state.

So, as human rights in general far from single out spheres of natural freedom in a world determined by politics and big government, all of them are based on social institutions, made by political and legal actions. The freedoms safeguarded by human rights do not imply the omission of state formalities but the adaptation of those to the corresponding freedom. The freedom of association is, thus, not violated by the provision of state formalities on the formal requirement of registration in the event of the foundation of an association, but each association has to be publically registered irrespective of the purpose of the association or the by-laws agreed upon by its members. So all human rights - the civil and political rights herein included - depend on a plethora of societal, political and social prerequisites. Therefore, also the social human rights should and can be qualified as their dependence on state legislation and public implementation is not atypical of human rights but in general complies with them as to being legally respected, socially protected and politically fulfilled. Social human rights can even more provide a good illustration of how these three dimensions of all human rights grew in importance and gained ground.

A further criticism against social human rights is their alleged lack of justiciability. ${ }^{28}$ Indeed their terms are vague and unclear as to their meaning and content. And it is on their basis difficult to predict what a beneficiary really can count upon. These rights are not only open to predicting what a beneficiary might specifically expect, nor is this openness of the right a characteristic which is observed only in the context of social human rights. As to their general and abstract content, all human rights are unclear and, hence, not easily grasped. Which actions are permitted under the freedom of belief, expression or of art? It is in each case quite difficult to find out - as the constitutional terms are broad, vague and open to interpretation. But this problem can and will be solved on the basis of case law, which has been established for the social human rights to a certain degree already as it was elaborated for a longer period of time for the classical human rights. So, in any respect case law and many existing fundamental standards stemming from such law might help to solve the problem of unclear human rights.

Also the quite frequently raised argument that social human rights are said to be unenforceable disregards the potential that legislation on human rights has developed. So the criticism seems to be a little bit circular, stating as an alleged consequence what

28 Daphne Barak-Erez and Aeyal Gross (eds), Exploring Social Rights (Hart Publishing 2007); Malcolm Langford (ed), Social Rights Jurisprudence (Cambridge University Press 2008). 
the argument tries implicitly to hinder. So the alleged shortcoming comes from the lack of willingness to take the existing law enforcement mechanism for granted.

And, finally, there is no profound difference to be noticed between the negative and the positive freedom, ${ }^{29}$ because all freedoms are at risk of being violated irrespective of their negative or positive dimension. Each violation of both positive or negative freedom indicates a lack of respect, a lacuna in protection or a deficit in the fulfilment of a human right. So, there is no fundamental objection against the adequacy and legitimacy of social human rights.

\section{IV.ii Structure of Social Rights}

\section{IV.ii.a Addressees of social rights}

From an international law perspective, social rights are addressed towards the state. But from the perspective of national law it is not primarily the state, but other individuals, which are quite often organised in social intermediaries such as social insurances, local communities or members of the workforce of a country, who are to make social rights become effective. This direction and determination of a social right becomes obvious for the right to work. As it is enacted as the right to work with freedom of choice of employer, ${ }^{30}$ it requires that a worker can find an employer, willing to employ him or her and to collaborate. The rights to decent housing or good health care do not imply that the state owns houses or has health care facilities at its disposal. These rights mean, however, that if these items are under private ownership, also house-owners, hospitals or medical doctors are bound to make the social rights become effective. Social rights are always included 'in social contexts that enable, hinder or preclude the realization of self-reliance in varying degrees'. ${ }^{31}$

The right to social security depends on solidarity established within the corporation organised as a social security institution apart from the solidarity prevailing in a state. Those who are covered by social security are not identical with the citizens of a given state, as social security covers also non-nationals due to their work or residence. This difference unveils a profound lacuna in the prevailing theory on 'social citizenship', ${ }^{32}$ which is so popular in the English-speaking world, as it clarifies that social security does not coincide with the idea of national solidarity! It has much more to do with the solidarity among those who are working and living in the same country. This difference matters in an internationally open society.

The social security system creates a framework of redistribution among the insured persons. Social rights are based on obligations and commitments imposed in a given society on its members. This role is not embedded in nationality but in residence and

29 Sandra Fredman, Human Rights Transformed (Oxford University Press 2008); Eberhard Eichenhofer, Soziale Menschenrechte im Völker-, europäischen und deutschen Recht (Mohr Siebeck 2012).

30 Art. 23 Universal Declaration of Human Rights; an example of that right is given by Judith Asher, The Right to Health. A Resource Manual for NGOs (Martinus Nijhoff 2010).

31 Gerald J Beyer, 'Economic Rights: Past, Present and Future', in Thomas Cushman (ed), Handbook of Human Rights (Routledge 2012) 291 at 301.

32 Thomas Humphrey Marshall, 'Citizenship and Social Class' in Thomas Humphrey Marshall and Tom Bottomore (eds), Citizenship and Social Class (Pluto Press 1992) 3 ff. 
work within a state. This integration implies not only entitlements, but imposes at the same time commitments as to finance and facilitates the system to fulfil its protective function and make, thus, social life become an effective and productive one. ${ }^{33}$ 'The importance of rights to welfare ... lies not only in the guarantee of a basic standard of living per se, but also ... in the fact that the latest the fullest enjoyment of the civil rights of citizenship is dependent on welfare if these rights are to be more than formal and real guarantees'. ${ }^{34}$ In this respect, social rights are important to create the preconditions under which civil society and democracy can flourish. ${ }^{35}$ Social rights enable human beings to use their civil rights and give democracy an 'added potency'. ${ }^{36}$ 'The idea of rights of welfare has also become linked with the idea of social justice' and hence 'confer[s] a social and economic state outside the market'. ${ }^{37}$

It 'involves the idea of a just distribution of resources and, therefore, a correction of the market outcomes. It also entails the idea that citizens' obligations do not mean mutual non-interference, for citizens have positive obligations, to provide resources for welfare which can be collected coercively through the tax system' ${ }^{38}$

\section{IV.ii.b Social rights and social duties}

Social rights encompass rights of action and rights of recipience: thus giving benefits as imposing burdens implies questions of distributive justice. This is a common feature of all social protection systems. The Beveridge Report stated that 'social security must be achieved by co-operation between the state and the individual'. 39 'Rights of action are the absences of obligation. On the other hand, rights of recipience of a person are rights which correspond to the duties of another person or people. ... All moral rights of recipience can be expressed in terms of duties, not all duties are expressible in terms of rights'. ${ }^{40}$

Social rights unveil as their main characteristic the necessary interrelation between rights and duties. This context is pointed out by Article 29 I of the Universal Declaration of Human Rights: 'Everyone has duties to the community in which alone the free and full development of his personality is possible'. So, all human rights of recipience correspond to duties of other human individuals. ${ }^{41}$

33 Jef van Langendonck, 'Freedom and Social Security', in L Mitrus (ed), Liber Amicorum Prof Dr habil. Andrzej Marian Swiatkowski, Studies in Labour Law and Social Policy (Rocznik 2009) 311 at 320.

34 Neville Harris, 'The Welfare State, Social Security, and Social Citizenship Rights', in Neville Harris (ed), Social Security Law in Context (Oxford University Press 2000) 3 at 23.

35 Ibid 23.

36 Ibid 31.

37 Raymond Plant, 'Citizenship, Rights, Welfare', in Jane Franklin (ed.), Social Policy and Social Justice (Polity 1998) 57.

38 Ibid.

39 Grainne McKeever, 'Balancing Rights and Responsibilities: The Case of Social Security Fraud' (2009) 16 JSSL 139 at 141; Lucy William, Philosophy of Private Law (Clarendon Press 2007) 333.

40 Hugh V McLachlan, Social Justice, Human Rights and Public Policy (Humming Earth 2005) 30 .

41 Ibid., 53; Sandra Fredman, Human Rights Transformed (Oxford University Press 2008) 65, 204. 
The right to social security unveils the conditionality ${ }^{22}$ of social rights in a double sense: firstly, these rights depend on qualifying conditions elaborated by law and to be fulfilled by the beneficiary's living circumstances and assessed as being fulfilled by the administration; and secondly, the beneficiary is exposed to series of actions in order to receive benefits, e.g., as an unemployed person actively to search for work or as injured person to be open to medical treatment, rehabilitation or vocational training. Benefits depend on administrations, which are capable of effectively charging the insured persons with the payment of contributions. Social rights are characterised by a collective component, they go hand in hand with social responsibilities - 'No rights without responsibilities!'43

In contrast to ecological rights, social rights are the rights of individuals, which are embedded in collective relations, which create rights and duties; whereas ecological rights are addressed primarily to certain groups of human beings, social rights intend to safeguard the well-being of each individual. Social security illustrates this clearly. In the case law of the European Court of Human Rights the right to social security assumes the legal character of property. ${ }^{44}$ This shows that social and civil rights are similar.

\section{IV.ii.c Social rights depend on legislation}

The conditions for social rights are to be created by acts of legislation. The first and most fundamental prerequisite is to make social rights feasible; this requires the establishment of institutions to administer and police social rights by acts of legislation. A series of requirements stem from these circumstances, which must be respected in order to adapt the right to the needs of the beneficiaries. The stakeholders - trade unions, employers' organisations and non-governmental organisations - should be integrated in the legislation to give them a voice. The debate on social legislation should be profound and accompanied by a public discourse in order to make the public and the beneficiaries aware of the rights to be enacted.

Additionally, social rights depend on a plethora of social and institutional conditions, also to be established by law. The right to work is bound to a whole range of potential employers and a public system of placement, a policy directed towards full employment - with many instruments on training, assistance and, if necessary, public employment and labour legislation. The same is true for the rights to decent housing or health care. All these human rights are to be built on the organisational capacity of the state, to regulate the labour market, housing and health care. The implicit condition, on

42 Eberhard Eichenhofer, Recht des aktivierenden Wohlfahrtsstaates (Nomos 2013).

43 Anthony Giddens, Beyond Left and Right (Polity 1994) 65.

44 Koua Poirrez v France Appl no 40892/98 (ECHR 30 September 2003); Gaygusuz v Austria Appl no 17371/90 (ECHR 27 September 2011); Stec v United Kingdom Appl nos 65731/01 and 65900/01 [2005] 41 EHRR SE 295, 51: 'In the modern, democratic State, many individuals are, for all or part of their lives, completely dependent for survival on social security and welfare benefits. Many domestic legal systems recognise that such individuals require a degree of certainty and security, and provide for benefits to be paid - subject to the fulfilment of the conditions of eligibility - as of right'; Mel Cousins, 'The European Convention on Human Rights, Non-Discrimination and Social Security: Great Scope, Little Depth?' (2009) 16 JSSL 120 . 
which the right to social security is built, is organisations establishing a relationship between a huge number of individuals confronted with the same social risk and the protection is based on solidarity. 'Solidarity is the child of interdependence, although not interdependence alone.' ${ }^{45}$

A law strengthening social solidarity constructed 'a realm of social rights, of moral equality and identity among all citizens, created by modern society's interconnectedness'. ${ }^{46}$ Social rights, thus, give shape to this interdependence among the covered persons, working or living in a given state. Due to this they do depend on institutions, which have to be established by acts of state legislation and are to be brought forward by the state and are accompanied by a bureaucracy. It foresees and attributes to those entitled a fair share of the outcome of the social product. ${ }^{47}$ So, the welfare state cannot be adequately understood without accepting bureaucracy as its backbone.

In this respect the fundamental social rights can be analysed as provisions to institute and establish institutional administrative frameworks, capable of making individual social rights become effective. These rights impose many commitments on the legislator. Thus, the primary addressee to bring about and make social rights matter is Parliament. This is free to decide on how the social goal is best achieved; but under a guaranteed social right it is not free to abstain from action. Thus, it has to make sure that individuals entitled to social rights can achieve a societal position in line with the given legal provision.

If these commitments are based on international law, the implementation of specific measures is imposed on the state. This leads to the impression that international social rights might undermine both democracy and sovereignty. But this is a double misconception: firstly, because all human rights limit democracy as they identify spheres of action beyond the discretion by the majority; and finally, under the post-World War II order of states, all states are deeply embedded in international and European law. Hence, all states have definitely lost their sovereignty, above all as far as human rights are concerned.

The fact, that all human rights are based on social circumstances and depend on legal provisions giving them shape and structure shows clearly that not only social human rights, but all fundamental civil and political human rights, have state power as their implicit precondition. ${ }^{48}$ The civil rights leave the creation of individual autonomy within a political community and political rights are made to give the individual a say in forming and executing state power. The latter are not meant to establish a political order apart from the state, but to integrate the citizens into the making of state policy in the framework of a democratic government within a given state.

So again, civil and political rights cannot be conceived as the legal status of an isolated individual living apart from both the state as society but as a means to frame -

45 Peter Baldwin, 'The Politics of Social Solidarity. Class Bases of the European Welfare State 1875-1975' (Cambridge University Press 1990) 32, 33.

46 Ibid 35.

47 Jürgen Habermas, Faktizität und Geltung (Springer 1992) 104 ff.

48 Chapter 5 in this volume; even in the 1793 French version of the Declaration of Human and Civil Rights it was definitely expressed: 'La déclaration des droits contient les obligations des législateurs' (the declaration of rights implies the obligation to enact laws). 
shape, limit and legitimate - the execution of state power in relation to individuals living in a given society. In this context the state is not bound to abstain from action, but to take measures. Parliament is, however, not only bound by these rights as such, but it is bound to find also the proper ways and means to make these rights become effective administratively and financially. So, human rights impose on the state the burden to make human rights become both effective and protective.

\section{IV.iii Justiciability and Enforceability of Social Rights}

'Scepticism directed against the potential justiciability of economic, social and cultural rights is commonplace, not only in the international law sphere, but also in many domestic law systems.' 49 'A standard objection to social rights is that they rest on the concept of needs, which is notoriously difficult to grasp, mostly because they are impossible to distinguish from preferences, so that one cannot determine with precision what really counts as needs.' 50

Human rights as part of international law serve as guiding principles for domestic politics; they are supported by monitoring mechanisms established on the global regional level. ${ }^{51}$ Based on the declarations of principles laid down in the Universal Declaration of Human Rights, since the 1990s a transnational 'jus commune of human rights' has begun to emerge. ${ }^{52}$ The Universal Declaration of Human Rights principles gained ground as a persuasive authority, it has been reproduced and, thus, strengthened by similar guarantees on the regional level. This development revives the idea of natural law, which was the initial theory upon which international human rights had been established. As the Universal Declaration of Human Rights principles became binding provisions under UN law and because Article 103 of the UN Charter prevails over other international provisions, international human rights have a binding effect on the states.

Do the various social rights give entitlements in substance? Could one ever imagine being entitled under a right to work to a specific workplace, under the right to health to be in good health for lifetime, and what about a right to welfare for the able-bodied. Are they entitled to be on the dole for life? So, one can not only ask: 'Do economic and social rights only exist on paper as part of treaties and constitutions to which governments often pay lip service at international fora?' 53 At the same time: are the

49 Yuval Shany, 'Stuck in a Moment in Time: The International Justiciability of Economic, Social and Cultural Rights', in Daphne Barak-Erez and Aeyal M Gross (eds), Exploring Social Rights: Between Theory and Practice (Hart Publishing 2007) 77, 78; Diane Roman, La justicibialité des droits sociaux: Vecteurs et resistances (Editions Pedone 2012).

50 Cecile Fabre, Social Rights under the Constitution. Government and the Decent Life (Oxford University Press 2000) 33.

51 Judith Asher, The Right to Health. A Resource Manual for NGOs (Martinus Nijhoff Publishers 2010).

52 Olivier De Schutter, International Human Rights Law (Cambridge University Press 2010) $31 \mathrm{ff}$.

53 Fons Coomans, 'Some Introductory Remarks on the Justiciability of Economic and Social Rights in a Comparative Context', in Fons Coomans (ed.), Justiciability of Economic and Social Rights. Experiences from Domestic Systems (Intersentia 2006). 
social rights in the last instance expressions of a Utopian thinking, which is not appropriate to the brutish world of competition, markets, in short, the world we are living in?

'Human rights are difficult to define, but in general terms, they are regarded as fundamental and undeniable claims or entitlements which are essential for life as a human being. ${ }^{54}$ It is true that when it comes to defining the concept of welfare, the latter assumed different forms in history and in comparative perspective a plethora of legal organisations of welfare is to be observed. The same is true when it comes to social security in which the conventional doctrine discerns an egalitarian Nordic, a conservative central European and a liberal, British approach. ${ }^{55}$

There is no doubt about the open and abstract character of human rights guarantees, but this is not peculiar to social rights, as it characterises all the provisions on human rights! All human rights are vague and 'all human rights are "social" by nature'.56 Social rights are based upon state power, as they depend on the ability of the state to build legal institutions by political measures and legal action. The social rights need public support, as they create individual rights by imposing obligations to others; the social contributions to pay are made mandatory to make the social rights become effective.

Thus by state legislation social human rights, enshrined in international, European and national constitutional law, are to be implemented by law. In a legal system based upon the rule of law, each entitlement to social welfare or social security has to be submitted to review by independent tribunals, which have to assess whether an administrative decision has been taken in accordance with the legal provisions.

In their role as part of an interventionist state, social commitments are becoming leading imperatives for legislative actions. It is a generally accepted principle that social rights are to be created in relation to the economic potential of a state and that the development of social rights is to be realised progressively. ${ }^{57}$ Hence, the state is also committed to protect those persons who cannot take part in the market due to individual restraints or deficits. The de-commodification of social services or goods and the payment of cash transfers is the sociological expression of delivering these items by means of law, instead of purchasing them on the market. The rationale behind the social strategy is to help those who cannot help themselves.

This is very often done by virtue of utilising market forces to meet social ends. So, state guarantee of social rights is possible in market economies under the assumption that each market economy is necessarily to be embedded in a publicly created legal order, determined to facilitate the market forces to cooperate and to protect the needy who cannot actively take part in the market process.

54 Manisuli Ssenyonjo, Economic, Social and Cultural Rights in International Law (Hart Publishing 2009) 9.

55 Gøsta Esping-Andersen, The Three Worlds of Welfare Capitalism (Cambridge University Press 1990).

56 Daphne Barak-Erez and Aeyal M Gross (eds), Exploring Social Rights: Between Theory and Practice (Hart Publishing 2007) 7.

57 Gerald J Beyer, 'Economic Rights: Past, Present and Future', in Thomas Cushman (ed), Handbook of Human Rights (Routledge 2012) 291, 300; Olivier De Schutter, International Human Rights Law (Cambridge University Press 2010) 740 ff. 
Social rights bring about a judicial incrementalism ${ }^{58}$ as they are to be defined under conditions of uncertainty, might have an important allocative impact and have significant implications for a large number of people. From this stems an attitude of judges to outline social rights in a general and tentative manner, to make Parliament implement appropriate rules and to avoid explicit delimitations, assessments and sanctions.

\section{THE HUMAN RIGHT TO SOCIAL SECURITY AS INTERNATIONAL AND EUROPEAN GUARANTEE}

\section{V.i United Nations}

In the United Nations the right to social security becomes important (a) under the Universal Declaration of Human Rights, (b) in the context of the International Covenant on Economic, Social and Cultural Rights (ICESCR), and (c) in the ILO legislation.

\section{V.i.a Universal Declaration of Human Rights}

Under Article 22 of the Universal Declaration of Human Rights 'everyone, as a member of society, has the right to social security'. This provision is universal as to the entitled persons. If everyone as a member of society has a right to social security, no differential treatment is permitted as to the social status, gender, age, nationality or a disability of the protected individual. All persons living or working in a society are to be included in the social protection system of this country. Nationality, as the link between an individual and the state which organises the protection, has no decisive role to play in the context of protection. The right is embedded in the membership within a society; this does not derive from nationality, but from factors which connect an individual with a state by social links - above all residence or work.

To determine the substantive scope of Article 22 of the Universal Declaration of Human Rights, Article 25 contains an important indication. In this provision at the first level the social human rights to assistance, health and housing are guaranteed: 'Everyone has the right to a standard of living adequate for the health and well-being of himself and his family, including food, clothing, housing and medical care and necessary services'. Additionally, Article 25 refers to 'the right to security in the event of unemployment, sickness, disability, old age and other lack of livelihood in circumstances beyond his control'. From this follows that the list of social risks mentioned by Article 25 is not limitative, but open to further circumstances beyond personal control. ${ }^{59}$

\section{V.i.b International Covenant on Economic, Social and Cultural Rights}

By the International Covenant on Economic, Social and Cultural Rights the principles laid down in the Universal Declaration of Human Rights, which had been understood

58 Jeff King, Judging Social Rights (Cambridge University Press 2013) 293 ff.

59 Jef van Langendonck, 'The meaning of the right to social security', in Jef van Langendonck (ed), The Right to Social Security (Intersentia 2007) 3, 5. 
as principles of morals and ethics and not intended as principles of law, had been translated into a binding, legally enforceable and effective mechanism of public international law. The economic, social and cultural rights, enshrined in the Covenant are made legally binding and the guarantees elaborated become enforceable. As to the two categories of social and civil human rights, there are two covenants established. Both are devoted to the two groups of rights, but both have the same intention of protection. Both covenants are transformed in the legislation of the transforming states as an integral part of their own law. ${ }^{60}$

On this basis Article 9 of the International Covenant on Economic, Social and Cultural Rights reads: 'The States Parties to the present Covenant recognize the right of everyone to social security, including social insurance.' This highlights that social insurance is seen as a means to foster social security.

A Committee on the International Covenant on Economic, Social and Cultural Rights supervises the states on whether their legislation is in accordance with these guarantees. The members of this Committee agreed upon criteria which should lead the interpretation and control of the Covenant. They are explicitly stated in the Limburg principles on the Implementation of the International Covenant on Economic, Social and Cultural Rights (1986) ${ }^{61}$ and the Maastricht Guidelines on Violations of Economic, Social and Cultural Rights (1997). ${ }^{62}$

As to these interpretative rules the human rights proclaimed in the Covenant should be emphasised. The states should 'take appropriate legislative, administrative, budgetary, judicial and other measures towards the full realization of such rights' (para 6). The commitment towards the full realisation of these rights is to be done progressively (para 8). A budget lacuna cannot be accepted as an objection for the full realisation of a right (para 10). If social security schemes are to be eliminated, the states have to provide for an adequate replacement. Each 'reduction or diversion of specific public expenditure, when such reduction or diversion results in the non-enjoyment of such rights' has to be 'accompanied by adequate measures to secure minimum subsistence rights for everyone' (para 14 b).

The UN Committee on Economic, Social and Cultural Rights ${ }^{63}$ gives a general comment No 19. Therein it underlines that the right to social security stands in relation to the guarantee of human dignity and the other human rights of the Covenant, since without social protection the capacity to realise full Covenant rights would not exist. ${ }^{64}$ The right to social security is characterised by three dimensions: it gives access and benefit in cash or kind in the various acknowledged cases of lack of work income; it does not provide for special standards, but leaves it to the states to give shape to this right. And, finally, due to the lack of sufficient protection under social security worldwide, there is still a long way to go to establish social security as a universal

\footnotetext{
60 John Veit-Wilson, 'Some Social Policy Implications of a Right to Social Security', in Jef van Langendonck (ed), The Right to Social Security (Intersentia 2007) 57, 65.

61 (1987) 9 Human Rights Quarterly 121; see Chapter 5 in this volume.

62 (1998) 20 Human Rights Quarterly 691; see Chapter 5 in this volume.

63 Ibid.

64 Frans Pennings, 'Historical and Theoretical Background of Standard Setting in Social Security', in Ulrich Becker, Frans Pennings and Tineke Dijkhoff (eds), International StandardSetting and Innovations in Social Security (Kluwer Law International 2013) 15, 16.
} 


\section{Research handbook on European social security law}

human right. In the light of this experience emphasis should be given to integrating the most vulnerable groups of society into the protection of social security. 65 Special attention is given by the Committee to retrogressions. They are not outlawed, but to be tested on whether they keep an eye on the most disadvantaged groups of society, which are not to be deprived of the protection they achieved previously. ${ }^{66}$ This links the International Covenant on Economic, Social and Cultural Rights guarantees with the conventions and recommendations enacted by the ILO. ${ }^{67}$

\section{V.i.c ILO}

The overall objective of the ILO is to obtain social justice worldwide through the promotion of decent work for all. One of the principal means of action of the ILO is the setting of international standards ... The standards serve as worldwide agreed guidelines or benchmarks for the adoption of national social policies and when ratified, they prevent countries from backsliding. But more important, once ratified by member states, ILO conventions become binding national law. This is a potentially powerful instrument in global social policy! 68

Social protection has been a central concern of the ILO's activities since its very beginning. As early as 1919 the International Labour Conference adopted in its first session a convention on social insurance. ${ }^{69}$ Among the conventions and recommendations on social security, Convention No. 102 is the 'flagship convention', ${ }^{70}$ as it includes all the nine branches of social security. Later conventions, e.g. those on pensions (No. 128), health care (No. 130), employment injuries (No. 121) and unemployment benefits (No. 168) set higher standards. Convention No. 157 establishes a comprehensive, all-embracing regime for the social security rights - a protection for migrant works on a global basis. ${ }^{71}$

65 Ibid, 17; Eibe Riedel, 'The Human Right to Social Security, Some Challenges', in Eibel Riedel (ed), Social Security as a Human Right (Springer 2007) 17, 22, 26.

66 Ibid, 26, 27.

67 Ibid, 22; apart from the ILO activities the UN pursues its own social policy by conventions on the rights of the child ([1989] 1577 United Nations, Treaty Series 3), persons with disability ([2006] 2515 Treaty Series 3) and all migrant workers and members of their families ([1990] A/RES/45/158); Ryszard Cholewinski, Paul de Guchteneire and Antoine Pécoud (eds), Migration and Human Rights. The United Nations Convention on Migrant Workers' Rights (Cambridge University Press 2009).

68 Ursula Kulke, Michael Cichon and Karana Pal, 'Changing Tides: A Revival of a Rights-Based Approach to Social Security', in Jef van Langendonck (ed), The Right to Social Security (Intersentia 2007) 13, 15.

69 ILO Recommendations No. 1 (1919), see also Conventions No. 18 (1925), 19 (1925), 24 (1927), 35 (1933).

70 Ursula Kulke, Michael Cichon and Karana Pal, 'Changing Tides: A Revival of a Rights-Based Approach to Social Security', in Jef van Langendonck (ed), The Right to Social Security (Intersentia 2007) 13, 15.

71 This topic is also dealt with by the International Convention on the Rights of Migrant Workers, see Ryszard Cholewinski, Paul de Guchteneire and Antoine Pécoud (eds), Migration and Human Rights. The United Nations Convention on Migrant Workers' Rights (Cambridge University Press 2009). 
Convention No. 102 does not specifically prescribe the manner in which health care and income security has to be organised by the states. There is no ideal type of policy elaborated which should be adopted by the member states. Instead of this, Convention No. 102 fixes minimum objectives on the basis of commonly agreed principles. It establishes the basis for social protection to be created and upheld and progressively developed by all the ILO member states. These standards refer to the percentage of the population protected: 20 per cent of the inhabitants or 50 per cent of the workers. It requires also a protection of at least three of the acknowledged nine social contingencies, and minimum expectations as to the level, duration and periodical adjustment of the benefits. ${ }^{72}$ It anchors a few constructive principles of social security as to the legal guarantee of the rights to benefits, the participation of employers and employees in the administration of the system, and a collective public financing out of taxes or contributions. If the system is financed by contributions the employee's share should not exceed half of the overall costs. In the calculation of this half, employment injury and family benefits should not be taken into account as both fall within the employer's responsibility.

Since 2001 the ILO has undertaken many initiatives to further the human right to social security by giving the debate on international standard setting a new approach: instead of a conventions-based approach a rights-based approach was initiated. ${ }^{73}$ This view of social security was proclaimed by the International Labour Conference 2001 and more precisely elaborated in documents such as: Social Security: A New Consensus ${ }^{74}$ Setting Social Security Standards in a Global Society ${ }^{75}$ and Social Security and the Rule of Law. ${ }^{76}$ The ILO Declaration on Social Justice for Fair Globalization, enacted at the 97th session of the International Labour Conference on 10 June 2008, underlined the double strategic approach for a further deepening of social security protection, both as to the persons covered (horizontal approach) and as to the benefit levels (vertical approach). In 2012, ILO Recommendation No. 202 was enacted to strengthen ILO Convention No. 102 and make the issue become more relevant to the international community.

72 Ibid 16.

73 Frans Pennings, 'Historical and Theoretical Background of Standard Setting in Social Security', in Ulrich Becker, Frans Pennings and Tineke Dijkhoff (eds), International StandardSetting and Innovations in Social Security (Kluwer Law International 2013) 15, 17; Kari Tapiola, 'Global Standards: The Policy of the ILO', in Ulrich Becker, Frans Pennings and Tineke Dijkhoff (eds), International Standard-Setting and Innovations in Social Security (Kluwer Law International 2013) 43.

74 ILO, Social Security: A New Consensus (ILO 2001).

75 ILO, Setting Social Security Standards in a Global Society (ILO 2008).

76 ILO, Social Security and the Rule of Law (ILO 2011). 


\section{V.ii Council of Europe}

Under the Council of Europe's legislation the right to social security is formally established in Article 12 of the European Social Charter as a specific human rights instrument. ${ }^{77}$ As to this it is stated:

With a view to ensuring the effective exercise of the right to social security, the Parties undertake:

1. to establish or maintain a system of social security;

2. to maintain the social security system at a satisfactory level at least equal to that necessary for the ratification of the European Code of Social Security;

3. to endeavour to raise progressively the system of social security to a higher level;

4. to take steps, by the conclusion of appropriate bilateral and multilateral agreements or by other means, and subject to the conditions laid down in such agreements, in order to ensure:

a. equal treatment with their own nationals of the nationals of other Parties in respect of social security rights, including the retention of benefits arising out of social security legislation, whatever movements the persons protected may undertake between the territories of the Parties;

b. the granting, maintenance and resumption of social security rights by such means as the accumulation of insurance or employment periods completed under the legislation of each of the Parties.

This right is supplemented by the right to social and medical help (Article 13 European Social Charter) and to social services (Article 14 European Social Charter). As to Article 12 of the European Social Charter the contracting states who are members of the European Council are to establish and develop a system of social protection, which complies with the ILO standards of Convention No. 102. These requirements are made even more demanding by the European Code of Social Security, which makes higher standards an obligation of the Council of Europe's member states, e.g., to provide for at least six of the nine branches of social security, whereas under the Convention No. 102 three branches suffice.

As to Article 12(1) of the European Social Charter, it is evident that as social security rights are embedded the establishment of social rights of such a system is an indispensable condition. The notion of social security is broad; it encompasses rights to social income and social services. ${ }^{78}$ The system of protection is to be established by each state in line with its own priorities. As to the personal scope of protection, a workor residence-based system can be erected; the decision on the system depends on to the priorities of the states. ${ }^{79}$ Article 12(2) of the European Social Charter underlines that an accurate protection of social security as a human right needs, additionally, an

77 David Harris and John Darcy, 'The European Social Charter' (Pail Institute 2001) 153 ff; Olivier De Schutter, 'The Two Lives of the European Social Charter', in Olivier De Schutter (ed), The European Social Charter: A Social Constitution for Europe (Bruylant 2010) 11, 29; Lenia Samuel, Droits sociaux fondamentaux. Jurisprudence de la Charte sociale européenne (Editions du Conseil de l'Europe 1997) $319 \mathrm{ff}$.

78 Matti Mikkola, Social Human Rights of Europe (Legisactio 2010) 298.

79 Ibid 304. 
elaborated statute, which more carefully and substantially identifies the cornerstones of the social security system to be established. As to Article 12(3) of the European Social Charter the system is to be developed progressively, this means bringing social security legislation from a 'lower' to a 'higher' level of human rights protection. But what is 'low' and 'high' in social protection? In the initial phase of the European Social Charter, social security progress was paralleled with economic expansion; under the conditions of a matured system of social protection also the costs and burdens imposed on the active generation as contributors of the social security became an issue. So, social progress means today a balanced system of protection bearable by the society and sustainable for the future generations of beneficiaries. So, the progressive development clause in the provisions is to be interpreted so as to make the social security system of each country keep pace with the development of the society at large. ${ }^{80}$

Article 12(4) of the European Social Charter makes it mandatory for the states to ascertain the right to social security in the international dimension. This encompasses equal treatment of all nationals of different countries and creating provisions to make social security entitlements become internationally effective by exporting benefits in cash, accumulating periods of coverage and protection spent under the legislation of different countries.

A further dimension of the protection of the right to social security in the framework of the Council of Europe's legislation identified in the activities of the European Court of Human Rights, which has to interpret the European Convention on Human Rights. Despite the fact that this Convention is about civil and political human rights, the case law of the European Court of Human Rights shows clearly that also social security rights have a deep link to civil and political human rights, so that these human rights guarantees also strengthen the right to social security. ${ }^{81}$

\section{V.iii European Union}

Article 6 of the Treaty of the European Union (TEU) integrates the EU Charter of Fundamental Rights (Charter) into the core of the primary legislation to which it previously belonged as a non-binding document of a more political and moral dignity than legal enforceability. As to Article 51 of the Charter both the EU organs and the Member States are bound by the Charter when applying EU law. So, the provisions of the Charter are not only relevant when assessing the actions taken by the EU, but the Charter binds and obliges also the Member States as far as they administer EU law or implement EU directives into the core of their domestic legislation. Both can happen in social security as to the - relatively few - directives which are relevant to social security and as to the social security co-ordination, whose rules are to be applied by the domestic social security administrations. The Charter provides under Title IV on 'solidarity' a whole range of social human rights (Articles 27 to 38). In Article 34 of the Charter the right to social security is formally stated:

80 Ibid 298, 313, 320.

81 On the further implications of these rules, extensively Slingenberg, Chapter 3 in this volume. 


\section{Research handbook on European social security law}

1. The Union recognises and respects the entitlement to social security and social services providing protection in cases such as maternity, illness, industrial accidents, dependency or old age, and in the case of loss of employment, in accordance with the rules laid down by Union law and national laws and practices.

2. Everyone residing and moving legally within the European Union is entitled to social security benefits and social advantages in accordance with Community law and national laws and practices.

3. In order to combat social exclusion and poverty, the Union recognises and respects the right to social and housing assistance so as to ensure a decent existence for all those who lack sufficient resources, in accordance with the rules laid down by Community law and national laws and practices.

The provision was one of the most controversial of the Charter. ${ }^{82}$ The provision is a compromise between more proactive versions and reluctance to safeguard Member States in their autonomy in social policy. Article 34 of the Charter proclaims the principle of solidarity, which is a key principle of the Charter; it also concurs with the commitment of the EU to social targets, social progress, a social market economy and the combating of social exclusion. ${ }^{83}$ The EU has to respect social protection as the central institution of the Member States. ${ }^{84}$ In addition it imposes on both the EU and the Member States ${ }^{85}$ the commitment to give access to social security benefits irrespective of nationality - also for third states' nationals. ${ }^{86}$

This right is to be guaranteed by the EU and the Member States to everyone. So, one might doubt whether under such a guarantee selective protection in social security above all as to the economic status as an employee or a self-employed person - is permitted. The conventional explanation that this difference is justified by the different ranges of protective need is not soundly proven, as the vulnerability to social risks is not bound to dependent work, but is also a huge challenge for all sorts of selfemployment. So, as to the human rights character of this guarantee, this right has to strengthen the most vulnerable members of a society. Neither distinctions nor omissions are justified when it comes to social protection in the context of the right to social security.

\section{CONCLUSION}

The human right to social security is both an integral and fundamental part of human rights legislation. It is an integral part as it coincides with other social rights, and it is

82 Angelika Nußberger, 'Art. 34 Rn. 8 ff', in Peter J Tettinger and Klaus Stern (eds), Kölner Gemeinschaftskommentar zur Europäischen Grundrechte-Charta (Beck 2006); Andrea Georgis, 'Artikel 34 No 2, 3, 4', in William BT Mock and Gianmario Denaro (eds), Human Rights in Europe: Commentary on the Charter of Fundamental Rights of the European Union (Carolina Academic Press 2008).

83 Angelika Nußberger, 'Art 34 Rn 54 ff', in Peter J Tettinger and Klaus Stern (eds), Kölner Gemeinschaftskommentar zur Europäischen Grundrechte-Charta (Beck 2006).

84 Ibid Rn 59 (Annotation).

85 Ibid Rn 104.

86 Ibid Rn 65, 69, 77, 106. 
a fundamental part as it lays the ground for an economically independent life for individuals, even when they are exposed to the vicissitudes of life, i.e., the contingencies that happen because independence is endangered due to living conditions beyond individual control. Social security is an extremely technical instrument and it is, therefore, difficult to grasp, but it is based on the easily understood idea that each one has a right and, hence, is obliged to take part in the formation of social rights.

The incorporation of social rights, i.e. the human rights to work, education, assistance, health and social security, underlines that human freedom is not only protected if the classical civil and political rights - the human rights of the first generation - are safeguarded, but that also the basic needs and entitlements in a work society have to be established, to establish a law which guarantees human dignity then conceived as the freedom from fear and want. When, hence, assessing the arguments against and in favour of fundamental social human rights, and sketching the various legal foundations of social human rights on the international, national and European level, it becomes clear that social human rights are in line with the principles of human rights legislation in general and, so, they are to implement and strengthen by international adjudication and monitoring. The human right to social security is not only a matter of right, but at the same time it imposes, like all social human rights, obligations on society at large. So like social human rights also the right to social security is based on a mix of rights and commitments both of the beneficiary and of society.

\section{BIBLIOGRAPHY}

Ackermann, Bruce and Anne Alstott (1999), The Stakeholder Society, New Haven: Yale University Press. Arendt, Hannah (1960), The Origins of Totalitarianism, New York: Harcourt Brace.

Armstrong, Barbara N (1932), Insuring the Essentials, New York: Macmillan.

Asher, Judith (2010), The Right to Health. A Resource Manual for NGOs, Leiden: Martinus Nijhoff Publishers.

Baldwin, Peter (1990), The Politics of Social Solidarity. Class Bases of the European Welfare State 1875-1975, Cambridge: Cambridge University Press.

Barak-Erez, Daphne and Aeyal M Gross. (eds) (2007), Exploring Social Rights: Between Theory and Practice, Oxford: Hart Publishing.

Becker, Ulrich, Frans Pennings and Tineke Dijkhoff (eds) (2013), International Standard-Setting and Innovations in Social Security, Alphen aan den Rijn: Kluwer Law International.

Berlin, Isaiah (1958), Two Concepts of Liberty, Oxford: Oxford University Press.

Berlin, Isaiah (1969), Four Essays on Liberty, Oxford: Oxford University Press.

Beyer, Gerald J (2012), 'Economic Rights: Past, Present and Future', in Thomas Cushman (ed.), Handbook of Human Rights, London/New York: Routledge, $291 \mathrm{ff}$.

Bilchitz, David (2008), Poverty and Fundamental Rights: The Justification and Enforcement of SocioEconomic Rights, Oxford: Oxford University Press.

Bosniak, Linda (2008), The Citizen and the Alien. Dilemmas of Contemporary Membership, Princeton and Oxford: Princeton University Press.

Cesaro, Jean-Francois (2011), L'égalité en droit social, Paris: LexisNexis.

Cholewinski, Ryszard, Paul de Guchteneire and Antoine Pécoud (eds) (2009), Migration and Human Rights. The United Nations Convention on Migrant Workers' Rights, Cambridge: Cambridge University Press.

Coomans, Fons (2006), 'Some Introductory Remarks on the Justiciability of Economic and Social Rights in a Comparative Context', in Fons Coomans (ed.), Justiciability of Economic and Social Rights. Experiences from Domestic Systems, Antwerp: Intersentia, 1 ff. 


\section{Research handbook on European social security law}

Cousins, Mel (2009), 'The European Convention on Human Rights, Non-Discrimination and Social Security: Great Scope, Little Depth?' JSSL, 16, 120.

De Burca, Grainne and Bruno de Witte (eds) (2005), Social Rights in Europe, Oxford: Oxford University Press.

De Schutter, Olivier (2010), International Human Rights Law, Cambridge: Cambridge University Press.

De Schutter, Olivier (2010), 'The Two lives of the European Social Charter', in Olivier De Schutter (ed.), The European Social Charter: A Social Constitution for Europe, Brussels: Bruylant, $11 \mathrm{ff}$.

Deakin, Simon (2005), 'The "Capability" Concept and the Evolution of European Social Policy', in Eleanor Spaventa and Michael Dougan (eds), Social Welfare and EU Law, Oxford/Portland: Hart Publishing, 3 ff.

Eichenhofer, Eberhard (2012), Soziale Menschenrechte im Völker-, europäischen und deutschen Recht, Tübingen: Mohr Siebeck.

Eichenhofer, Eberhard (2013), 'Constitutional Guarantees of Social Protection', in K. Ketscher et al (eds), Velferd og rettferd, Festskrift til Asbjorn Kjonstad, 70 ar, Oslo: Gyldendal Juridisk, 127.

Eichenhofer, Eberhard (2013), Recht des aktivierenden Wohlfahrtsstaates, Baden-Baden: Nomos.

Eide, Asbjorn (ed.) (2001), Economic, Social and Cultural Rights, Dordrecht: Martinus Nijhoff Publishers. Epstein, Abraham (1933), Insecurity: A Challenge to America, New York: American Economic Association. Esping-Andersen, Gøsta (1990), The Three Worlds of Welfare Capitalism, Cambridge: Cambridge University Press.

Fabre, Cecile (2000), Social Rights under the Constitution. Government and the Decent Life, Oxford: Oxford University Press.

Fredman, Sandra (2008), Human Rights Transformed, Oxford: Oxford University Press.

Georgis, Andrea (2008), 'Article 34', in William BT Mock and Gianmario Denaro (eds), Human Rights in Europe: Commentary on the Charter of Fundamental Rights of the European Union, Durham: Carolina Academic Press.

Giddens, Anthony (1994), Beyond Left and Right, Cambridge: Polity.

Glendon, Mary Ann (2001), A World Made New, New York: Random House.

Habermas, Jürgen (1998), Faktizität und Geltung, Frankfurt am Main: Springer.

Harris, David and John Darcy (2001), The European Social Charter, 2nd edition, Washington: Pail institute.

Harris, Neville (2000), 'The Welfare State, Social Security, and Social Citizenship Rights', in Neville Harris (ed), Social Security Law in Context, Oxford: Oxford University Press.

Hepple, Bob (2011), Equality. The New Legal Framework, Oxford and Portland: Hart Publishing.

ILO (2001), Social Security: A New Consensus, Geneva: ILO.

ILO (2008), Setting Social Security Standards in a Global Society, Geneva: ILO.

ILO (2011), Social Security and the Rule of Law, Geneva: ILO.

Kaufmann, Christine (2007), Globalisation and Labour Rights. The Conflict between Core Labour Rights and International Economic Law, Oxford and Portland: Hart Publishing.

King, Jeff (2013), Judging Social Rights, Cambridge: Cambridge University Press.

Kulke, Ursula, Michael Cichon and Karana Pal (2007), 'Changing Tides: A Revival of a Rights-Based Approach to Social Security', in Jef van Langendonck (ed.), The Right to Social Security, Antwerp: Intersentia $13 \mathrm{ff}$.

Langford, Malcolm (2008), Social Rights Jurisprudence, Cambridge: Cambridge University Press.

MacCormick, Neil (1982), 'Legal Right and Social Democracy', in Neil MacCormick, Legal Right and Social Democracy, Essays in Legal and Political Philosophy, Oxford: Oxford University Press 1 ff.

McKeever, Grainne (2009), 'Balancing Rights and Responsibilities: The Case of Social Security Fraud', JSSL 16, $139 \mathrm{ff}$.

McLachlan, Hugh V (2005), Social Justice, Human Rights and Public Policy, Glasgow: Humming Earth.

Marshall, Thomas Humphrey (1992), 'Citizenship and Social Class', in Thomas Humphrey Marshall and Tom Bottomore (eds), Citizenship and Social Class, London: Pluto Press 3 ff.

Mikkola, Matti (2010), Social Human Rights of Europe, Helsinki: Legisactio.

Nußberger, Angelika (2006), 'Article 34', in Peter J Tettinger and Klaus Stern, Kölner Gemeinschaftskommentar zur Europäischen Grundrechte-Charta, Munich: Beck.

Paine, Thomas (1791), The Right of Man, London, www.ushistory.org/paine/rights/index.htm.

Pennings, Frans (2007), 'The Meaning of International Standards in Social Security', in Jef van Langendonck (ed.), The Right to Social Security, Antwerp: Intersentia.

Pennings, Frans (2013), 'Historical and Theoretical Background of Standard Setting in Social Security', in Frans Pennings, Ulrich Becker and Tineke Dijkhoff (eds), International Standard-Setting and Innovations in Social Security, Alphen aan den Rijn: Kluwer Law International 15. 
Plant, Raymond (1998), 'Citizenship, Rights, Welfare', in Jane Franklin (ed), Social Policy and Social Justice, Cambridge: Polity $57 \mathrm{ff}$.

Ramcharan, Bertrand G (2008), 'Norms and Machinery', in Thomas G Weiss and Sam Daws (eds), The Oxford Handbook on the United Nations, Oxford: Oxford University Press 443.

Rawls, John (1971), A Theory of Justice, Oxford: Oxford University Press.

Riedel, Eibe (2007), 'The Human Right to Social Security, Some Challenges', in Eibe Riedel (ed), Social Security as a Human Right, Berlin/Heidelberg: Springer $17 \mathrm{ff}$.

Rimlinger, Gaston (1971), Welfare Policy and Industrialization in Europe, America and Russia, Hoboken: John Wiley \& Sons Inc.

Roman, Diane (2012), La justicibialité des droits sociaux: Vecteurs et résistances, Paris: Editions Pedone.

Roosevelt, Franklin D (1941), 'The Annual Message to the Congress, January 6th, 1941', in Samuel Rosenman, The Public Papers and Addresses of Franklin D Roosevelt, Vol. VI (War - and Aid to Democracies), New York $663 \mathrm{ff}$.

Roosevelt, Franklin D (1950), 'Speech from January 11th, 1944. 'For unless there is security here at home there cannot be lasting peace in the world - Message to the Congress on the State of the Union', in Samuel Rosenman, The Public Papers and Addresses of Franklin D Roosevelt, Vol. VIII (Victory and the Threshold of Peace), New York 1950, 32.

Samuel, Lenia (1997), Droits sociaux fondamentaux. Jurisprudence de la Charte sociale européenne, Strasbourg: Editions du Conseil de l'Europe.

Sen, Amartya (1992), Inequality Reexamined, New York: Russell Sage Foundation.

Shiman, David A (1999), Economic and Social Justice, A Human Rights Perspective, Minneapolis: Human Rights Resource Center.

Ssenyonjo, Manisuli (2009), Economic, Social and Cultural Rights in International Law, Oxford: Hart Publishing.

Tapiola, Kari (2013), 'Global Standards: The Policy of the ILO', in Frans Pennings, Ulrich Becker and Tineke Dijkhoff (eds), International Standard-Setting and Innovations in Social Security, Alphen aan den Rijn: Kluwer Law International, 43.

Van Langendonck, Jef (2007), 'The Meaning of the Right to Social Security', in Jef van Langendonck (ed.), The Right to Social Security, Antwerp: Intersentia.

Van Langendonck, Jef (2009), 'Freedom and Social Security', in L Mitrus (ed), Liber Amicorum Prof. Dr. habil. Andrzej Marian Swiatkowski, Studies in Labour Law and Social Policy, Krakow: Rocznik.

Veit-Wilson, John (2007), 'Some Social Policy Implications of a Right to Social Security', in Jef van Langendonck (ed.), The Right to Social Security, Antwerp: Intersentia 57.

William, Lucy (2007), Philosophy of Private Law, Oxford: Clarendon Press.

Young, Iris Marion (1990), Justice and the Politics of Difference, Princeton: Princeton University Press.

Yuval, Shany (2007), 'Stuck in a Moment in Time: The International Justiciability of Economic, Social and Cultural Rights', in Daphne Barak-Erez and Aeyal M. Gross. (eds), Exploring Social Rights: Between Theory and Practice, Oxford: Hart Publishing. 